\title{
Refuge
}

Canada's Journal on Refugees

Revue canadienne sur les réfugiés

\section{No One to Bear Witness: Country Information and LGBTQ Asylum Seekers}

\section{Douglas McDonald-Norman}

Volume 33, Number 2, 2017

URI: https://id.erudit.org/iderudit/1043066ar

DOI: https://doi.org/10.7202/1043066ar

See table of contents

Publisher(s)

Centre for Refugee Studies, York University

ISSN

0229-5113 (print)

1920-7336 (digital)

Explore this journal

Cite this article

McDonald-Norman, D. (2017). No One to Bear Witness: Country Information and LGBTQ Asylum Seekers. Refuge, 33(2), 88-100.

https://doi.org/10.7202/1043066ar
Article abstract

This article examines the use of country information in determining claims for refugee status based on sexual orientation or gender identity. Limitations to country information remove diverse individual experiences from the "historical record" and obstruct marginalized individuals' ability to prove their claims for protection. Discrimination and marginalization may be echoed and perpetuated within country information itself, which privileges certain voices over others. MD (same-sex-oriented males: risk) India CG [2014], the United Kingdom's current "country guidance” decision on claims for protection by same-sex oriented men from India, is examined in light of these themes.
Copyright (c) Refuge: Canada’s Journal on Refugees, 2017

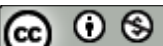

This document is protected by copyright law. Use of the services of Érudit (including reproduction) is subject to its terms and conditions, which can be viewed online.

https://apropos.erudit.org/en/users/policy-on-use/ 


\title{
No One to Bear Witness: Country Information and LGBTQ Asylum Seekers
}

\author{
DOUGLAS MCDONALD-NORMAN ${ }^{1}$
}

\section{Abstract}

This article examines the use of country information in determining claims for refugee status based on sexual orientation or gender identity. Limitations to country information remove diverse individual experiences from the "historical record" and obstruct marginalized individuals' ability to prove their claims for protection. Discrimination and marginalization may be echoed and perpetuated within country information itself, which privileges certain voices over others. MD (same-sex-oriented males: risk) India CG [2014], the United Kingdom's current "country guidance" decision on claims for protection by same-sex oriented men from India, is examined in light of these themes.

\section{Résumé}

Cet article étudie l'utilisation de renseignements sur le pays d'origine afin de déterminer les demandes de statut de réfugié en lien avec l'orientation sexuelle et l'identité de genre. Les limites en matière de renseignements sur le pays d'origine effacent du registre historique diverses expériences individuelles et font obstruction à la capacité qu'ont des personnes marginalisées de justifier leur demande de protection. La discrimination et la marginalisation peuvent être répétées et prorogées par l'information même délivrée par les pays, qui privilégie certaines voix sur d'autres. À la lumière de ces thèmes de réflexion est étudié le document du Upper Tribunal (Royaume-Uni) MD (same-sex oriented males: risk) India CG [2014], qui établit les lignes directrices actuelles de pays en matière de décision concernant les demandes de protection pour les hommes homosexuels provenant d'Inde.

\section{Introduction}

ountry information is an essential part of refugee status determination (RSD). Information about countries from which asylum seekers have fled ("countries of origin") can help to prove that claimed experiences of past persecution occurred and that asylum seekers would be at risk of harm in future. ${ }^{2}$ However, country information must not be used uncritically. It can never provide an objective, exhaustive guide to events in a particular country, as if recounted by an omniscient narrator of events. All sources of country information are selective, edited accounts of particular circumstances, of varying focus and breadth. These accounts must be interpreted rather than merely taken at face value, having due regard to their biases, priorities, and intended usage.

The potential of country information to mislead, and the corresponding need for informed and close analysis, is particularly acute in assessing the claims of asylum seekers whose claims for protection are based on their real or perceived sexual orientation or gender identity (referred to in short as "LGBTQ asylum seekers"). Sexuality is fluid, intensely personal, and potentially experienced in highly variable ways from person to person and within each individual's own lifetime. ${ }^{3}$ Country information can provide only limited corroboration for how individual sexual acts or identities will be experienced, valued, or treated, or for the potentially significant distinctions between sexual minority groups (and 
how such groups are perceived by agents of persecution) in countries of origin.

This article examines the use of country information in assessing claims for protection based on sexual orientation or gender identity. In particular, this article discusses the extent to which country information may be distorted by "privilege" and insufficient regard to diverse, individual, and intersectional experiences of sexuality and gender, with the United Kingdom Upper Tribunal's "country guidance" decision in $M D$ (same-sex-oriented males: risk) India CG [2014] ("MD") analyzed as a case study. This article draws upon the author's experiences as a former researcher and solicitor with an Australian law firm with a significant practice in refugee law.

\section{Country Information: History and Controversies}

"Country information" is information about other nations used in RSD. It is not only used to examine conditions in countries of origin; it may extend, for example, to information about countries through which asylum seekers have travelled in order to reach the jurisdiction in which their claims for protection are assessed. Country information can include very general information, like information about the history, geography, or demographics of a particular nation or a particular region. It can also be very specific, like information about particular locations, events, or individuals. It can arise from any number of sources. Although reports from governments and NGOs have traditionally been used in RSD, increasingly widespread access to the Internet and social media has expanded the range of materials used to corroborate claims about country conditions (and claims for asylum in general), 5 including blog posts and information provided via social media. It can be produced for a variety of purposes: to chronicle conditions in a particular country, to draw attention to particular situations or particular types of abuse, or to support claims for asylum, whether claims by particular groups from particular countries or individual claims.

The weight afforded to particular sources of country information will vary from source to source. Reports by wellestablished international NGOs like Human Rights Watch or Amnesty International, or the United States Department of State's Country Reports on Human Rights Practices, ${ }^{6}$ may be afforded greater weight in decision-making because of the stature of the organizations that have produced them, ${ }^{7}$ even over specialist groups looking into particular types of abuse or speaking out on behalf of particular groups. ${ }^{8}$ This is problematic. This weighting reinforces a professionalized, expertdriven, and "technocratic" model of fact-finding in human rights advocacy in which elite (and/or Western) voices, concerns, and methods are privileged. ${ }^{9}$

Country information is essential in RSD because it provides necessary context for asylum seekers' claims to fear persecution if removed from the countries in which they have sought asylum. Country information cannot, however, resolve each and every case on its own; "individualized" assessment is key to the appropriate functioning of RSD. ${ }^{10}$ In particular, the "credibility" of asylum seekers' claims about why they fear harm in their countries of origin must be examined; decisionmakers must determine whether asylum seekers are telling the truth about who they are and why they are seeking asylum. Furthermore, country information cannot provide an exhaustive, comprehensive, and objective account of every instance of persecution in a particular nation, especially where such persecution is merely feared or prospective.

Like any other form of fact-finding or research in human rights advocacy, country information will inevitably be shaped by "politics, culture, judgment, power, and many other dimensions," rather than a mere account of the "facts."11 Country information may exaggerate the scale or extent of particular abuses, in order to draw attention to a cause or puncture public complacency. Alternatively, NGOs operating in countries of origin may downplay some abuses, or present them in more careful and measured language, so as to emphasize positive trends, maintain good relationships with local governments, or cater to the prejudices of intended audiences (within the country of origin or elsewhere). These practices, even where they serve a political purpose or make sense in a context of partial improvement, may present an inadvertently rosy picture of conditions (and endanger claims for asylum) when viewed outside that context. A portrait of improving conditions may be interpreted as a portrait of good conditions, when nothing of the sort was intended.

Country information may also be produced by governments, such as the Immigration and Refugee Board of Canada (IRBC)'s National Documentation Packages ${ }^{12}$ and research reports collating information in response to specific inquiries, ${ }^{13}$ or the Australian Department of Foreign Affairs and Trade (DFAT)'s reports from overseas embassies. ${ }^{14}$ This information may either replicate factors that distort NGO reporting (for example, where, as in IRBC reports, official reports rely upon collation of material produced in unofficial sources) or prove subject to governments' desire to present other nations in a positive or negative light, depending on their alliances and political interests. ${ }^{15}$ Hence, both the collation and the production of information by countries of asylum may be problematic. Even government decisions on which forms of country information to prioritize, and which forms to downplay, may be subject to these same pressures. For example, Australia's decision to dictate that RSD officials must take account of DFAT's country information assessments, with no equivalent dictate to consider any other form of country information, was understood and reported as an effort to "toughen up the asylum seeker claims process." 16 
Calls for caution in how country information is employed and interpreted are nothing new. ${ }^{17}$ Goodwin-Gill and McAdam, for example, have observed that although documentary evidence, including country information, "has a seductive air, often seeming sufficient to decide the case," country information that is not related personally to the applicant "often gives only a general impression, more or less detailed, of what is going on." 18 This "seductive air" derives from the seeming certainty and clarity of country information, as compared to the perceived subjectivity or unreliability of witness testimony. ${ }^{19}$ Like other asserted "facts" in human rights advocacy, this appeal of country information derives from "the residual appeal of the notion that there are things that are 'true,' 'evident,' or 'concrete' when all else appears fickle, contestable and subjective." ${ }^{20}$ Where it is frequently perceived that "refugee claimants tell lies"21 -a particularly common and pernicious view in the context of claims based on sexual orientation ${ }^{22}$-and other forms of corroboration may be lacking, country information bears the sheen of perceived objectivity. This allows it to play a crucial role in the "surveillance of authenticity" that dominates contemporary RSD. ${ }^{23}$ Nonetheless, as Macklin has written, country information "usually paint[s] a canvas with broad, crude brush strokes." 24 To this end, the Hungarian Helsinki Committee have asserted that country of origin information "cannot reflect the entire reality in countries of origin," that no source can be regarded as entirely objective, and that "COI is not a lie detector; it provides the wider context for the assessment of an asylum claim, yet it cannot tell whether the applicant is truthful, neither can it decide whether the claim is well-founded." 25

There is another line of critique that stresses the uneasy historical antecedents of "country information." The collection and collation of information was a crucial means to establish and maintain colonial control; ${ }^{26}$ the contemporary practice of building "archives" of country information cataloguing human rights abuses, including abuses on account of sexual orientation or gender identity, have been questioned as the potential reiteration of "older colonial tropes" of the essentialized, intolerant, archaic "other" situated in contrast to the tolerant, accepting jurisdiction of refuge ${ }^{27}$ - jurisdictions that, in the context of claims on the basis of sexual orientation or gender identity, have disproportionately proven to be former colonial powers or settler colonies. ${ }^{28}$

Issues have also raised with the use of country information in assessing claims for asylum based on sexual orientation or gender identity. The notorious use of tourist guides as evidence of the toleration of same-sex sexual conduct has drawn widespread condemnation. ${ }^{29}$ Millbank has noted difficulties in drawing conclusions about "plausibility" of claims from country information, ${ }^{30}$ including deeming relationships to be implausible on the basis of endemic societal homophobia or criminalization-a form of reasoning under which "the claim of virtually every asylum seeker who has had, or attempted, a same-sex relationship in their country of origin is implausible because of the inherent risk it entailed." ${ }^{31}$ LaViolette has examined the history of, and ongoing difficulties within, Canadian usage of country information regarding LGBTQ asylum seekers, ${ }^{32}$ while Rehaag has stressed the need to "disaggregate" the treatment of different groups within the sweeping category of "LGBTQ" in country information. ${ }^{33}$ While building on these pioneering works, however, this article differs in several respects: its integration of practical insights from the author's experiences as a legal practitioner in Australia, its focus on questions of "profile," "privilege," and intersectionality, and its integration of theoretical critique with close analysis of one particular decision (the Upper Tribunal's decision in $M D$ ).

Despite this history of criticism and debate, the use of country information still remains problematic, even given improvements in this regard (in particular, in the documentation of abuses against sexual minorities) since the early 1990 os. ${ }^{34}$ As borne out by the author's experiences in practice, decision-makers still assume that country information is exhaustive, accurate, and universal in its application in a way that is not matched by the actual sources available-or, of course, by any source that could ever possibly become available. As explained below, these practices are particularly damaging in the context of claims for asylum by LGBTQ people.

\section{Suffering in Silence: Difficulties in Corroborating Diverse Experiences}

\section{"Low-Profile" or "Ordinary" Applicants}

Very few applicants for asylum will be able to point to country information that is about them, personally, and that independently corroborates who they are, why they fear harm in their country of origin, and what will happen to them if they return. ${ }^{35}$ In most cases, therefore, asylum seekers will be required to corroborate their claims for protection by reference to country information about how similarly situated people are treated in their countries of origin. Such information may be expressed in general terms-for example, the assertion that "Tamils throughout [Sri Lanka], but especially in the north and east, reported security forces regularly surveilled or harassed members of their community." 36 It may also consist of references to the experiences of specific individuals other than the applicant whose claims are being considered-for example, the assertion that "an overseas travel ban on human rights activist Balendran Jeyakumari ... was imposed for an indefinite period." 37

Even this information, however, may be of limited usefulness or applicability. Whereas country information generally 
abounds with coverage of the treatment of "high-profile" victims (whether that profile predates their experiences of persecution or is a result of their unique experience of persecution), it is often less capable of providing a full account of the lives of "ordinary," "low-profile" people, and of how they are likely to be regarded by potential agents of persecution. Although, for example, attacks on prominent LGBTQ individuals or attacks with unusually severe consequences or characteristics may receive media attention, not every act of homophobic violence will receive equivalent coverage-and still less in outlets to which RSD officials have access. This has implications beyond merely meaning that "ordinary" applicants cannot provide direct corroboration for claimed attacks; it can lead to the distorted impression that only high-profile individuals are at risk, or that the small sample of abuses that are publicised are, in fact, the only instances of such attacks.

This lack of evidence regarding the treatment of "ordinary" individuals may result from a focus upon high-profile incidents of violence, or "only the most egregious" situations, ${ }^{38}$ rather than the broader effects of discrimination, ostracism, and social stigma-paralleling longstanding allegations that international NGOs unduly neglect deprivations of social and economic rights in their reportage. 39 This focus upon particular forms of abuse may also derive from the fact that such abuses can retain their shocking or shameful quality removed from context (because of the universal comprehensibility of physical harm), and hence remain recognizable to various imagined audiences of "country information"-such as readers of newspapers based in the West, privileged communities in countries of origin, or constituencies invested in the work of international NGOS.

The question of "privilege" under the Refugees Convention is not new. It has, for example, previously been considered in terms of the unique opportunities enjoyed by individuals able to reach countries of asylum, as opposed to equally deserving individuals "left behind" (popularized by the notion of "queue jumpers"); 40 in terms of gender, including "refugee law's bias towards recognition of masculinised experiences"; ${ }^{41}$ or by reference to the disproportionate chances of success in RSD enjoyed by applicants with legal assistance. $4^{42}$ However, it is also possible to speak of the privileges enjoyed by certain applicants in RSD through the disproportionate representation of the experiences of similarly placed people in country information, and the corresponding disadvantages faced by other (often "ordinary") applicants whose experiences do not receive the same coverage. Individuals who enjoy politically or personally privileged positions in countries of origin-whether in terms of gender, race, class, social standing, or otherwise-may enjoy greater opportunities to have their experiences reproduced in country information. This inequality is compounded by difficulties faced by NGOs, particularly NGOs without international backing, in investigating and publishing information. ${ }^{43}$ Beyond chronicling disadvantages, how these "privileged" individuals experience and express their sexual orientation or gender identity may differ from less-privileged individuals-contributing to what Juss terms "the conceptualisation today of refugee rights as bourgeoisie rights." 44

These "privileges" enjoyed by some LGBTQ people are, of course, no answer to the disadvantages that these same "privileged" applicants will face on other fronts. Individuals may enjoy a privileged position in publicising their struggle and in representation in sources of country information, or other forms of privilege within their country of origin generally, while at the same time facing serious risks of persecution on account of their sexual orientation or gender identity. Not even the experiences of these individuals can be assumed to receive appropriate coverage, whether because state persecution of LGBTQ people may extend to the suppression of international or national groups that advocate for their cause 45 or even because of homophobia of domestic human rights bodies who would otherwise champion civil rights against the state. ${ }^{46}$

Distortion in favour of particular incidents, particular individuals, or particular subgroups is not restricted solely to LGBTQ claimants. It is often difficult to establish an endemic pattern of abuses, or to assert the frequency with which abuses occur, on the basis of country information that attests to past examples of persecution, simply because the day-to-day experiences of "ordinary" individuals are difficult to deduce or infer from the unrepresentative sample of abuses that do receive reportage. 47 The unique experiences of high-profile individuals must be understood in terms of their specific circumstances-that is, whether they are more or less likely to suffer particular forms of abuse as a result of their personal profile and its sources. Those experiences may have limited use in assessing the experiences of other people who possess different levels of privilege or disadvantage..$^{48}$

\section{Intersectional Claims}

Asylum seekers may have multiple, overlapping claims for protection. These claims cannot be assessed in a vacuum; instead, the "potential cumulative effect" of an applicant's claims and personal circumstances must be assessed. ${ }^{49}$ Even if no single part of an asylum seeker's profile would of itself be sufficient to attract adverse interest, individuals may be at risk of persecution because aspects of their profile may exacerbate the risks associated with other aspects. For example, lesbians, bisexual women, or trans women may face risks of persecution as a result of their gender identity or sexual orientation and because of discrimination against women in 
general, while, in turn, facing greater risks than they would face on account of any single one of these characteristics. Millbank notes in this regard that claims for protection brought by lesbian asylum seekers in Canada and Australia disproportionately involve experiences of sexual assault, even beyond the high rates of sexual violence reported by LGBTQ claimants for asylum as a whole as part of their claims for protection. ${ }^{50}$ These claims should not be viewed simply in terms of violence against women, or in terms of the accessibility of support services intended for women as a whole; the role of state and societal homophobia in prompting such attacks or restricting access to redress must be considered. ${ }^{51}$

The term LGBTQ needs dissection in this regard. Although this initialism is used as shorthand in this article, the term disguises the extraordinary diversity of human experiences of sexuality and gender by conflating the potentially very different experiences of different sexual minorities. Where, for example, country information documents the experiences of men who engage in same-sex sexual conduct, it should not be assumed to reflect the experiences of lesbians, bisexual people, or trans people. Where country information is produced by gay men - who may, by virtue of their gender, face reduced social barriers in telling and publicizing their stories than cis or trans women-it should not be assumed to be free from societal prejudices against lesbians, bisexual people, or trans women (potentially even exhibiting sexism and/or transphobia) or immune to, or even conscious of, the privileges enjoyed by gay men by virtue of their gender. More broadly, country information produced by one subset of the LGBTQ community may replicate or ignore that subgroup's privileges (social, economic, gendered, or otherwise).

Intersectional claims create difficulty in using country information. Sources assessing or documenting risks faced by LGBTQ people may be (understandably) written with regard to harm attributable explicitly to victims' sexual orientation or gender identity, without focusing on elevated risks faced by some individuals on account of different characteristicscarrying out, in the process, what Kimberlé Crenshaw terms the "elision of difference" in non-intersectional identity politics. ${ }^{52}$ Even where such accounts purport to merely document the experiences or cultural assumptions of particular groups, they may inappropriately conflate the experiences of various sexual minorities-for example, erasing the distinct experiences of lesbians through blanket references to "the non-gendered but male-centred category of "homosexual," or through the use of country information solely regarding the treatment of gay men to assess the claims of lesbian, bisexual, or trans asylum seekers. 53

Similarly, reports of racial or religious discrimination may focus upon those aspects without considering intersectional forms of harm for particular members of minority communities, including LGBTQ people who are also members of racial or religious minorities. Various overlapping facets of identity shape individual experiences of "realisation or violation of human rights"; 54 reports purporting to document such violations should make clear (as far as possible) varied experiences of persecution or the extent to which persecution may result from an aggregate of different factors. 55 Accounts of the causes of particular human rights abuses must draw upon, not merely make "passing references" to, ${ }^{56}$ the diverse experiences of differently placed individuals.

As noted above, country information may disproportionately represent the experiences of "privileged" individuals-whether because those individuals whose experiences are studied or who are able to attest to particular conditions speak the same language as interlocutors, because they are familiar with civil society or legal mechanisms to publicize particular abuses (or are themselves directly involved in producing country information), or because their experiences are seen as more relatable or of greater interest to intended audiences. Individuals who suffer from multiple intersecting forms of disadvantage face correspondingly greater barriers to having their stories heard and, in turn, to ensuring that their disadvantage is reflected in available sources of country information; they risk being diminished by the preference in human rights fact-finding for a "single story" in which diverse experiences are blurred or diminished. 57 This tendency may be compared to asylum advocates' presentation of "simplistic, even derogatory characterizations of asylum seekers' countries of origin, as areas of barbarism or lack of civility in order to present a clear-cut picture of persecution. ${ }^{58}$ Decision-makers, advocates, and governments alike have an interest in the preservation of neat, simple stories of who is at risk in other nations and who is not, from the point of view of researching claims, placing claims within a Convention framework and deciding claims. The experience of intersectional persecution, in which individuals' claims do not turn on singular characteristics capable of expression in template submissions or being dispensed with in template decisions, cuts against this interest. (The dangers of undue generalization or "simplicity" in this regard are evident in the case study of $M D$, considered below.)

\section{"Discreet" or "Ashamed" Applicants}

Not all asylum seekers have necessarily suffered persecution. Past harm is not a prerequisite for refugee status, which turns instead upon whether individuals have a "well-founded fear" of persecution if removed to their country of origin. Although RSD officials may grant greater credence to a fear of harm if that harm has, in fact, occurred in the past, a fear can be credible even if applicants have been lucky or cautious enough to ensure their own safety to date. In particular, 
asylum seekers may have been able to escape harm in the past by concealing their identities, or those aspects of themselves that would otherwise have attracted persecution. They cannot, however, be expected or required to resume such secrecy if removed to their countries of origin, even if it has kept them safe to date. 59

LGBTQ asylum seekers may not have been open about their orientation or identity prior to leaving their country of origin. They may, for example, have concealed these aspects because of their own "feelings of shame and the consciousness of being the subject of disapproval or disgrace" as a result of prevailing societal homophobia, ${ }^{60}$ including internalized homophobia. ${ }^{61}$ The fact that many LGBTQ people in nations with persecutory laws or societal customs do live "quietly" or "discreetly," whether by choice or fear, makes it difficult to prove the risks that they would face if they were to be open about their sexual orientation or gender identity.

In examining country information about states where most LGBTQ people hide their identities, it can be difficult to determine the level of risk that individuals would face if they were to reveal their sexual orientation or gender identity. Where individuals in these circumstances do suffer harm, they may fail to report it, whether to state authorities or to NGOS, for fear of further discovery. It may not be clear if reported incidents of abuse represent isolated events unrepresentative of broader social attitudes or are, in fact, the inevitable or likely consequences for those few individuals whose sexuality is open or discovered. That is to say, one cannot necessarily extrapolate from circumstances of widespread repression and concealment what would happen to individuals who refuse to conceal their sexual orientation or gender identity, simply because these individuals are so rare and so exceptional. Silence in country information creates the illusion of safety.

To the extent that the experiences of some LGBTQ people in countries of origin are known, RSD officials must consider the extent whether such experiences are representative of the LGBTQ population as a whole (or, to be precise, of that particular subset to which an individual applicant belongs) and whether those experiences reflect the likely outcome of LGBTQ asylum seekers being open about their sexual orientation or gender identity upon return to their country of origin. In doing so, RSD officials must consider whether individuals who are able to openly profess their sexual orientation or gender identity in their country of origin, and whose experiences are known from country information, are exceptional in some respect-for example, whether they enjoy economic, social, or political capital that allow them to be open about their sexuality in a way that most individuals would not, and hence whether individuals who would otherwise be too discreet or ashamed to reveal their true orientations or identities would face entirely different, and potentially far graver, circumstances upon their return. (This requires, again, distinctions to be drawn within the category of "LGBTQ.")

\section{Atypical Applicants}

Individual experiences of sexuality and gender are uniquely personal. ${ }^{62}$ Even where asylum seekers' understandings of their sexual orientation or gender identity are informed by culture, or by participation in a given subculture, everyone will understand and express their sexual orientation and/or gender identity in a manner informed by their own experiences and outlook. RSD officials must not assume that particular, culturally specific modes in which sexuality may be expressed or manifested will determine, or even influence, asylum seekers' lived experiences-whether such modes are the product of RSD officials' own cultures or are predominant in the countries from which asylum seekers have come. ${ }^{63}$ RSD officials should not, for example, assume that individuals who fear harm because they have engaged in same-sex sexual conduct identify with any particular sexual minority or as possessing a given orientation or identity. This is because of the extent to which self-identification may be shaped by cultural context, including shame and stigma, and, more broadly, because individual narratives of "self" should not be assumed to be predictable or uniform in this manner. ${ }^{64}$ The process of relating to another individual's experiences of sexuality and culture, and in turn considering these experiences in terms of the criteria for refugee status, is one that requires "empathy and imagination." 65

Whereas country information may be used to provide a general impression of the circumstances of a particular group in a particular nation, or to provide some basis for assessing whether claimed actions or events are plausible, it cannot substitute for individualized assessment. The fact that other individuals, even individuals from a similar personal or cultural background, acted or were treated in a particular manner does not mean that this would be precisely replicated in every subsequent circumstance. In particular, the fact that given actions-whether by the asylum seeker, the feared agents of persecution, or someone else entirelyare not "reasonable" does not mean that such actions are not "plausible." Just as, for example, it may be plausible for politically committed individuals to act upon and express their political beliefs even where it is not in their interests to do so, ${ }^{66}$ so too individual actions are not always purely the result of context (that is, what their cultural or historical background dictates) or a utilitarian calculus; people do not always act consistently or rationally. ${ }^{67}$ Country information, in demonstrating how similarly placed individuals would act, cannot be used to discount claims that a person has acted 
in an exceptional or atypical manner. ${ }^{68}$ Unlikely events still happen.

This assumption of uniformity poses particular difficulties for LGBTQ asylum seekers who do not present in a manner that comports with the stereotypical assumptions of decision-makers of how LGBTQ people "ought" to act, whether in their own country or in the asylum seeker's country of origin. Such determinations turn to a significant extent upon whether claimed behaviour fits within "expected norms." 69 The entire spectrum of human sexual identity cannot be captured by stereotypical assumptions of this kind.

As Rehaag has documented,70 bisexual asylum seekers face particular difficulty in this regard, whether because of the continued belief among decision-makers (or, indeed, among individual advocates) that "heteronormative gender roles and same-sex sexual desire are somehow mutually exclusive" 71 or simply because decision-makers and advocates seek to fit individual sexual orientations or identities within settled, if unsatisfactory, dichotomies of "innate," "immutable" personal characteristics ${ }^{72}$ for ease of explanation or disposition 73 - contrary to lived experiences of fluid sexual identities. ${ }^{74}$ These damaging assumptions stem from and perpetuate the "invisibility" of bisexual experiences. 75 As a result, bisexual asylum seekers may be disadvantaged through the preponderance of "expected gay narratives" in societies in which asylum is sought (even as a product of gay activism itself). ${ }^{76}$ Women may similarly be disadvantaged because of the extent to which their sexual or gender identity self-formation may differ from that of men, 77 given the dominance of male voices and narratives in the countries in which asylum is sought (or even among drafters of country information).

These limits to country information must be borne in mind in its interpretation and use. The rejection of "stereotypy" and undue homogeneity in this regard is important in ensuring appropriate outcomes in RSD, in resisting a broader tendency towards "cultural arrogance," 78 in rejecting one particular model of the "acceptable" LGBTQ refugee upon asylum seekers and in preventing a regime in which asylum seekers are forced to curtail individual self-expression or manifestations of identity inconsistent with "the refugeegranting nation's image of the ideal refugee." 79

\section{Applicants Who Fear Harm from Inconsistently Applied Policies or Laws}

In some cases, a nation's criminal law may formally prohibit same-sex conduct or relationships while at the same time seldom leading to formal prosecutions. (India is one of these nations. How this situation has been viewed in practice in RSD is explored in the case study of $M D$ considered below.) Prosecutions are not the only way in which such laws are employed. Formal criminal prohibitions may be used to justify arrests, blackmail, or abusive behaviour by the state, or to legitimize discriminatory and oppressive behaviour by non-state actors (secure in the knowledge that the state will not intervene to protect sexual minorities). While country information may be able to document formal prosecutions and to record how frequently they occur, researchers face far greater obstacles to determining how often and on what scale these lower-level forms of abuse arising from prohibition occur. As LaViolette writes, "It is difficult to rebut the presumption of state protection when human rights documentation is unavailable or provides little information on attitudes and actual practice." 80

Even where, for example, the state maintains a formal position of neutrality or tolerance, this may not be honoured in practice. State officials may continue to commit abuses against LGBTQ people in spite of nominal guarantees of human rights, whether because LGBTQ people are unable to access redress against blackmail or extortion or because the state is incapable of restraining its own agents from acting upon societal homophobia or transphobia. Alternatively, violence against LGBTQ people may be regional or localized, whether because of repressive laws at the subnational level or because government officials in some provinces or districts act differently from their counterparts elsewhere in the nation. State laws should not be used as "a proxy for the composite repression within the state," whether such repression is exerted by state or non-state actors. ${ }^{81}$ The extent to which nominal laws are, in practice, modulated by other moral and social norms must be reflected in the production and use of country information.

Country information speaks in terms of probability, not certainty. It cannot speak of the precise outcomes of particular situations, or the precise treatment to which particular individuals would be subjected upon their return. It merely provides a basis for determining the likelihood of particular scenarios. This is particularly important in assessing the potential consequences of laws, policies, or state practices. Decision-makers cannot simply take the existence of a particular law, or the lawfulness of a given practice, to mean that that law will be applied uniformly in all circumstances. They must instead take into account factors such as corruption, scope for arbitrary or capricious behaviour by state officials, and (crucially for present purposes) the extent to which laws will be differently applied against LGBTQ people (or, alternatively, against different segments of the LGBTQ community)-including, for example, the use of laws that do not explicitly criminalize same-sex sexual conduct to prohibit such conduct in practice. ${ }^{82}$

Denial of access to justice has lasting effects in this regard. The arbitrary and unpredictable enforcement of laws thrives 
in an environment where marginalized communities (including LGBTQ people) are incapable of accessing the courts or enjoying legal or logistical help in preparing and presenting claims. Exclusion of LGBTQ people from presenting claims or defending themselves within the formal legal system also prevents abuses of these kinds from being reported or brought to light within country information; brief, cursory trials or summary decisions are far easier to conceal than sustained legal challenges to unjust legal or societal barriers. Discrimination and marginalization in countries of origin are reflected, even if partially, within country information, and hence may be replicated within the RSD process itself.

\section{Applicants Who Fear Harm from Non-State Actors and Families}

Many LGBTQ asylum seekers fear that they will be harmed because of their sexual orientation or gender identity by family members, neighbours, or other members of the community, and that the state will be unable or unwilling to redress such abuses. It is generally accepted that the Refugees Convention provides protection against the actions of non-state actors, even where the state is merely unable, as opposed to unwilling, to provide protection. ${ }^{83}$ (Individuals may also, as in $M D$, fear both state and non-state actors.)

Feared abuses by non-state actors may be very difficult to corroborate with country information, which is far better equipped to discuss state policies, and risks resulting from state action, than risks arising from societal or familial violence. State actions can often be described in relatively uniform terms, applicable to large classes of people. State actions can even be attributed to particular documents or laws and are in turn capable of redress through "top-down legal-institutional reforms." ${ }^{44}$ Risks arising from social or family attitudes are inchoate, highly variable, and resistant to generalization. Country information may, for example, be able to attest to widespread societal intolerance, but it cannot (usually) substantiate claims that an individual applicant's family are uniquely homophobic or transphobic, or lend credence to threats by particular non-state actors-whether families, clerics, or vigilante groups-to harm a person in a particular way if that person returned. (This is related to refugee law's broader problem in connecting the legal category of "persecution" to the complexities in practice of "contingencies of structural violence," 85 and the "state-centricity of human rights law" in general. ${ }^{86}$ ) This lack of information potentially contributes to a "simplifying tendency", of both advocates and decision-makers, in how circumstances or attitudes in other countries are regarded, ${ }^{87}$ or else to a tendency to regard undocumented abuses as being insufficiently severe to constitute "persecution." 88
Decision-makers must remain sensitive to the fact that not all risks can be corroborated, even by deduction from the experiences of others recorded in country information. Adverse inferences should not necessarily be drawn about applicants' credibility or the probability of future harm simply because their experiences are the product of societal attitudes rather than state policies. Such inferences must also be avoided where the agents of persecution feared by the asylum seeker, whether a particular family or even a particular individual, are outliers or unrepresentative in this regard (and not easily proven). Individuals' ability to live and love as they choose cannot be understood solely in terms of those individuals' relationships with the state in their countries of origin.

Female applicants may face particular disadvantages in this regard. As Millbank has noted regarding hate crimes in Australia, "Lesbians face significantly more 'private' violence than gay men-they are more likely to be harassed and assaulted at home or at work rather than on the streets, and more likely to be attacked by men known to them, such as neighbours or former partners." ${ }^{89}$ Claims based upon treatment of this kind in asylum seekers' countries of origin have historically faced significant difficulties in being characterized as Convention-related ${ }^{\circ}$ or as reaching the level of severity necessary to amount to "persecution." 91 In addition, they are less likely to receive the level of attention in country information directed towards more "visible" forms of persecution (such as violence or penal sanctions), including because these same social attitudes may exclude women's stories from available sources.

\section{Case Study: MD (same-sex-oriented males: risk) India CG}

MD is a gay man and a citizen of India. Because of his sexual orientation, he was expelled from his family home, he lost his employment in Mumbai, and he was arrested, detained, and beaten by police in India. ${ }^{22} \mathrm{He}$ applied for asylum in the United Kingdom in November 2007. His claims for asylum were finally rejected by the Immigration and Asylum Chamber of the Upper Tribunal on 12 February 2014-two months after the Supreme Court of India's decision in Koushal v Naz Foundation ("Koushal")93 affirmed the constitutionality of section 377 of the Indian Penal Code. Section 377 prohibits "carnal intercourse against the order of nature" and is widely understood to criminalize same-sex sexual conduct.

In $M D$, the tribunal found that neither MD, nor "same-sex oriented males" in general, would face a "real risk" of persecution if removed to India. The tribunal's findings in $M D$ constitute a "country guidance" decision-that is, its findings on which groups are at risk are binding upon future British 
decision-makers in asylum cases. ${ }^{94}$ It is hence itself a form of country information. This decision has also shaped the UK Home Office's Country Information and Guidance on claims for asylum based on sexual orientation and gender identity from Indian nationals. 95 The decision's character as a "country guidance" decision is central to this article's criticisms of its findings. The tribunal did not consider solely whether MD would be at risk, but expressed its findings on the risks faced by the broader class of "same-sex oriented males." This is a very broad category, overlapping with but not encompassing (or necessarily encompassed within) the category of "LGBTQ people in India." The breadth and artificiality of this category (given the extent to which it groups together a wide array of subgroups with which individuals may more readily identify) creates difficulty in providing precise guidance for how claims from this group should be regarded.

The tribunal considered various sources of country information, including reports from the UK Home Office, the us Department of State, the research divisions of RSD institutions in Canada and Australia, and numerous news reports. ${ }^{96}$ The tribunal devoted far more attention in its decision, however, to the written and oral evidence of Dr. Akshay Khanna, at that time a research fellow with the Institute of Development Studies at the University of Sussex. The tribunal acknowledged Khanna's evidence regarding the limited reporting and varying impact of abuses ${ }^{97}$ and his emphasis on differential treatment of gay people in India based on class. As Khanna stated, "If one is explicit about being gay, and is not upper class, it would be difficult to find both housing and employment" or to be part of a cohabiting relationship, ${ }^{98}$ with poor and working-class same-sex-oriented males "being most likely to face extreme violence, exclusion and discrimination."99 Khanna's evidence was that "samesex desiring' males, except those in the upper classes," were at risk of violence, police extortion, and societal discrimination in India, with LGBT persons in general suffering from a lack of police protection. ${ }^{100}$

In reaching this view, Khanna highlighted limits to available information. For example, while section 377 has rarely led to prosecutions in the higher courts, "that is not to say that the provision has not been used in the lower courts,"101 with no national records to enable a comprehensive analysis. ${ }^{102}$ Despite Khanna's caution, the tribunal was satisfied that such prosecutions are extremely rare at every level of the judiciary, given "the dearth of examples of such prosecutions before us." 103 Equivalent reasons were given, with far less justification, for rejecting Khanna's evidence of endemic police violence against LGBTQ persons-legitimized and shielded by the existence of section 377-in India. Noting the existence of "a significant LGBT rights network of NGOS in India" and litigation in support of LGBTQ rights, the tribunal asserted (even while accepting that many abuses by police go unreported) that "had the practice of violence and blackmail of LGBT persons by the police been at the level Khanna suggested it is, or at such a level that it could be said that there is a real risk to any particular same-sex oriented male, we would have expected this to have been better reflected by the examples of such treatment given in the evidence before us."104 (As explored above, there are myriad potential explanations for such silences in country information.)

The tribunal hence concluded that police violence, extortion, and blackmail against same-sex oriented males in India is not "so prevalent as to constitute a real risk to any given same-sex oriented male, whatever their class or status in Indian society" (emphasis added). ${ }^{105}$ The tribunal did not accept that this state of affairs would be altered by the Supreme Court's decision in Koushal. ${ }^{106}$

Were the tribunal merely assessing MD's claims for protection (rather than to formulate a country guidance decision), it could have found merely that MD had not established that he would face a real risk of police violence, extortion, and blackmail upon his return to India (despite his past experiences of abuse by police). In issuing a "country guidance" decision, however, the tribunal instead established guidelines for the assessment of claims by all "same-sex oriented males" from India seeking asylum in the United Kingdom. Even to the extent that same-sex oriented men in India do not uniformly face a real risk of persecution, regardless of their class or status-in India, as elsewhere, class and social status are significant factors in how same-sex-oriented males, and LGBTQ people in general, relate to the state and police-the tribunal needed to disaggregate how class and status in Indian society relate to the risks faced by same-sexoriented males, including from the police. In doing so, the tribunal might even have accepted that abuses against LGBTQ persons from disadvantaged groups are underreported, even if unwilling to accept the claimed extent of this underreporting for the community as a whole.

The tribunal similarly did not accept that violence by non-state actors demonstrates "that there is a real risk to any particular individual of suffering ill treatment at the hands of non-state actors," 107 finding that Khanna's evidence in this regard contained "an element of overstatement." ${ }^{108}$ Even where individuals" personal circumstances create a real risk of harm in their home area, the tribunal found that "it would not, in general, be unreasonable or unduly harsh for an open same-sex oriented male (or a person who is perceived to be such), who is able to demonstrate a real risk in his home area because of his particular circumstances, to relocate internally to a major city within India" (emphasis added). ${ }^{109}$

The phrase "in general" hides substantial variation. The tribunal's decision presumes that it would be "reasonable" 
for an individual to relocate within India without disaggregating the broad category of "same-sex oriented males" and considering risks arising from membership of different sexual minority groups, different ways in which sexuality is expressed or substantial diversity of class, race, and religion. ${ }^{110}$ In defence of the tribunal, it is open to individual applicants to whom the country guidance decision in $M D$ may apply to argue that it does not apply to their circumstances or to press for exclusion from the decision's broad ambit. Nonetheless, decision-makers and authors of country information must ensure that these subtle distinctions are not merely waved away by noting that their findings are expressed in "general" terms, and that diverse lived experiences of discrimination and persecution (shaped by privilege and class position) are appropriately acknowledged.

The tribunal hence found that, while MD may face some discrimination if removed to India, this discrimination would not amount to persecution, ${ }^{111}$ and that MD would not face a real chance of persecution from the state or from nonstate actors, "particularly in one of the major cities." ${ }^{112} \mathrm{MD}$ was not granted protection in the United Kingdom.

Like any form of country information, country guidance decisions are undoubtedly difficult to craft. They cannot provide an exhaustive account of the experiences of entire groups, particularly groups so broad as "same-sex oriented males in India." Nonetheless, some approaches to the production and employment of country information are inherently flawed. These include proceeding on assumptions that the absence of particular groups from country information indicates their safety, or that the absence of particular forms of abuse from country information indicates their non-occurrence. ${ }^{113}$ They also include assertions in general terms about the experiences of a group by reference to the security enjoyed by a portion of that group, with only cursory acknowledgment of the extent to which those experiences may be mediated by other forms of disadvantage.

\section{Conclusion}

The limitations of available country information should not serve as a cause for cynicism or hopelessness. Country information remains a powerful, indeed indispensable tool in RSD, even given such limitations. As Alston and Knuckey write with regard to human rights advocacy more broadly, "At a certain point, decisions have to be made on the basis of the best available evidence." 114 Similarly, in RSD, decisions on whether claims for protection are well founded must ultimately be made on evidence that is inevitably imperfect to some degree, and decision-makers must compensate for such imperfections (the "fragility of facts" 115 ) as far as they can instead of rejecting any source that falls short of an imagined ideal of perfection. ${ }^{116}$
Nonetheless, these limits do exist and can potentially have severe effects on the assessment of the claims of LGBTQ asylum seekers. Decision-makers need to be conscious of the individual circumstances of applicants before them, including that limited country information about those particular circumstances is not of itself evidence of the absence of abuses; that those individual circumstances may themselves be the result of repressive societal attitudes or public policies; that persecution is not recorded merely by unblinking, objective, omniscient narrators, and that persecution affects even the means by which it is reported, related, and condemned; and that every asylum seeker's sexual orientation or gender identity intersects with other elements of their identity. Individual experiences of sexuality and gender cannot and should not be "generalized" or assumed to follow uniform patterns.

\section{Notes}

1 This article is based on a paper presented at the Fourth LAssnet Conference, India Habitat Centre, New Delhi, 10-12 December 2016. The author thanks Jess McDonaldNorman, Laurie Berg, Nikki Edwards, Roopashi Khatri, Rupali Samuel, Maggie Sheen, Danish Sheikh, and Mrinalini Shinde for their assistance, encouragement, and comments in preparing that paper. All errors remain the author's own.

2 RSD is not unique in this regard; like other forms of human rights advocacy, it is centred in large part upon fact-finding, even given significant differences between fact-finding in human rights advocacy and ordinary judicial processes. See Philip Alston and Sarah Knuckey, "The Transformation of Human Rights Fact-Finding: Challenges and Opportunities," in The Transformation of Human Rights Fact-Finding, ed. Alston and Knuckey (Oxford: Oxford University Press, 2016), 3; Frédéric Mégret, "Do Facts Exist, Can They Be "Found," and Does It Matter?", in Alston and Knuckey, Transformation of Human Rights Fact-Finding, 29.

3 Laurie Berg and Jenni Millbank, "Constructing the Personal Narratives of Lesbian, Gay and Bisexual Asylum Claimants," Journal of Refugee Studies 22 (2009), 208-11.

$4 M D$ (same-sex-oriented males: risk) India CG, [2014] UKUT 00065 (IAC) [MD].

5 Rosemary Byrne, "The Protection Paradox: Why Hasn't the Arrival of New Media Transformed Refugee Status Determination?", International Journal of Refugee Law 27 (2015): $625-48$.

6 United States Department of State, Country Reports on Human Rights Practices, http://www.state.gov/j/drl/rls/ hrrpt. This influence is not new and is not restricted to the United States: David A. Martin, "Reforming Asylum Adjudication: On Navigating the Coast of Bohemia," University of Pennsylvania Law Review 138 (1990): 1310. When I was a practitioner, I used to call the release of the Country 
Reports on Human Rights Practices "Country Information Christmas."

7 This observation is based on the author's experiences as a practitioner. The frequency with which these organizations" reports are employed is corroborated by Catherine Dauvergne and Jenni Millbank, "Burdened by Proof: How the Australian Refugee Review Tribunal Has Failed Lesbian and Gay Asylum Seekers," Federal Law Review 31 (2003): 309.

8 Nicole LaViolette, "Independent Human Rights Documentation and Sexual Minorities: An Ongoing Challenge for the Canadian Refugee Determination Process," International Journal of Human Rights 13 (2009): 443-4.

9 See Dustin N. Sharp, "Human Rights Fact-Finding and the Reproduction of Hierarchies," in Alston and Knuckey, Transformation of Human Rights Fact-Finding, 69-88.

10 As Martin noted in 1990, the individualized character of assessment under the Refugees Convention had not (and arguably still has not) penetrated public perceptions of what a refugee is: "Reforming Asylum Adjudication," $1270-2$.

11 Alston and Knuckey, "Transformation of Human Rights Fact-Finding," 8.

12 National Documentation Packages are available at http:// www.irb-cisr.gc.ca/Eng/ResRec/NdpCnd/Pages/ndpcnd .aspx.

13 The Immigration and Refugee Board's reports, although produced for Canadian RSD, are employed by lawyers, researchers, and RSD officials around the world. They can be found at http://www.refworld.org/publisher/IRBC.html.

14 Although these reports play a critical role in Australian RSD, they are no longer published online.

15 In the 1980s, country information produced for the purposes of RSD in the United States "[was] biased towards denying asylum to applicants from friendly countries and granting asylum to applicants from hostile countries": Matthew E. Price, Rethinking Asylum: History, Purpose and Limits (Cambridge: Cambridge University Press, 2009), 92.

16 Samantha Hawley and Jane Norman, "Tribunals Ordered to Consider New Country Assessments When Deciding on Asylum Claims," AM, 17 July 2013, http://www.abc.net.au/ news/2013-07-17/refugee-tribunals-ordered-to-considernew-country-information/4824788; see also Douglas McDonald, "Simply Impossible: Plausibility Assessment in Refugee Status Determination," Alternative Law Journal 39 (2014): 244 .

17 Indeed, the title of this article reflects that of one of the earliest entrants in this field: Henry G. Watkins, "Credibility Findings in Deportation Proceedings: 'Bear[ing] Witness unto the Truth," Georgetown Immigration Law Journal 2 (1987): 231-94.

18 Guy Goodwin-Gill and Jane McAdam, The Refugee in International Law, 3rd ed. (Oxford: Oxford University Press, 2007), 547.

19 The perceived limitations of witness testimony as a reliable or credible source of evidence are, of course, not solely restricted to refugee law and are the cause of longstanding complaint and critique, even in other fields of law; for a venerable example in the Australian context, see, e.g., John V. Barry, "The Problem of Human Testimony," Australian Law Journal 11 (1938): 317. Such complaints are, however, voiced with particular frequency in refugee law because so often there are only limited sources other than witness testimony to corroborate claims for protection.

20 Mégret, "Do Facts Exist," 28.

21 Dauvergne and Millbank, "Burdened by Proof," 308; see also Pia Zambelli, "Hearing Differently: KnowledgeBased Approaches to Assessment of Refugee Narrative," International Journal of Refugee Law 29 (2017): 20-1. For the political context and significance of this attitude, see, e.g., Michael Kagan, "Is Truth in the Eye of the Beholder? Objective Credibility Assessment in Refugee Status Determination," Georgetown Immigration Law Journal 17 (2003): $368-71$.

22 See, e.g., Jenni Millbank, "From Discretion to Disbelief: Recent Trends in Refugee Determinations on the Basis of Sexual Orientation in Australia and the United Kingdom," International Journal of Human Rights 13 (2009): 398-9.

23 David A.B. Murray, Real Queer? Sexual Orientation and Gender Identity Refugees in the Canadian Refugee Apparatus (London: Rowman \& Littlefield International, 2016), 50.

24 Audrey Macklin, "Truth and Consequences: Credibility Determination in the Refugee Context" (conference paper, International Association of Refugee Law Judges, 1998), 137, cited in Jenni Millbank, “The Ring of Truth': A Case Study of Credibility Assessment in Particular Social Group Refugee Determinations," International Journal of Refugee Law 21 (2009): 1.

25 Hungarian Helsinki Committee, Credibility Assessment in Asylum Procedures: A Multidisciplinary Training Module, 2013, http://helsinki.hu/wp-content/uploads/CredibilityAssessment-in-Asylum-Procedures-CREDO-manual.pdf, 7.

26 See, e.g., Bernard S. Cohn, Colonialism and Its Forms of Knowledge: The British in India (Princeton: Princeton University Press), 3.

27 Murray, Real Queer?, 118.

28 Ibid., 119.

29 See, e.g., LaViolette, "Independent Human Rights Documentation," 449; Millbank, "From Discretion to Disbelief," 394.

30 Millbank, "Ring of Truth," 19-22.

31 Ibid., 20.

32 LaViolette, "Independent Human Rights Documentation."

33 Sean Rehaag, "Patrolling the Borders of Sexual Orientation: Bisexual Refugee Claims in Canada," McGill Law Journal / Revue de Droit de McGill 53 (2008): 90.

34 LaViolette, "Independent Human Rights Documentation," 444; see also Nicole LaViolette, "Coming Out to Canada: The Immigration of Same-Sex Couples under the Immigration and Refugee Protection Act," McGill Law Journal / Revue de Droit de McGill 49 (2004): 1000. 
35 Indeed, individuals who are sufficiently well-known that their views and exploits have been publicized in credible sources of country information may face even greater obstacles to fleeing their countries of origin, because of the corresponding level of scrutiny and control that they may face.

36 United States Department of State, 2015 Country Reports on Human Rights Practices: Sri Lanka, 13 April 2016, http:// www.refworld.org/docid/57161206c.html.

37 Ibid. As discussed above, such bans are one reason why applicants who are sufficiently high-profile to warrant specific mention in available country information may not be able to seek asylum abroad.

38 LaViolette, "Independent Human Rights Documentation," 447.

39 Sharp, "Human Rights Fact-Finding," 73-4.

40 For an examination of popular sentiment in this regard, see, e.g., Fiona H. McKay, Samantha L. Thomas, and Susan Kneebone, "It Would Be Okay If They Came through the Proper Channels': Community Perceptions and Attitudes toward Asylum Seekers in Australia," Journal of Refugee Studies 25 (2012): 117, 128.

41 Jenni Millbank and Catherine Dauvergne, "Forced Marriage and the Exoticization of Gendered Harms in United States Asylum Law," Columbia Journal of Gender and Law 19 (2010): 898; see also Jenni Millbank, "Imagining Otherness: Refugee Claims on the Basis of Sexuality in Canada and Australia," Melbourne University Law Review 26 (2002): 163.

42 Millbank, "Imagining Otherness"; see also Jacqueline Bhabha, "Internationalist Gatekeepers?: The Tension between Asylum Advocacy and Human Rights," Harvard Human Rights Journal 15 (2002): 161.

43 LaViolette, "Independent Human Rights Documentation," 448.

44 Satvinder Juss, "Sexual Orientation and the Sexualisation of Refugee Law," International Journal on Minority and Group Rights 22 (2015): 134.

45 LaViolette, "Independent Human Rights Documentation," 448.

46 Ibid., 442.

47 Sharp, "Human Rights Fact-Finding," 73-4.

48 Shreya Atrey, "The Danger of a Single Story," in Alston and Knuckey, Transformation of Human Rights Fact-Finding, 166.

49 DZADH $v$ Minister for Immigration, [2012] FMCA 1112 at para 33.

50 Jenni Millbank, "Gender, Sex and Visibility in Refugee Claims on the Basis of Sexual Orientation," Georgetown Immigration Law Journal 18 (2003): 77. Similar observations have been made in the United Kingdom: uk Lesbian \& Gay Immigration Group, Missing the Mark: Decision Making on Lesbian, Gay (Bisexual, Trans and Intersex) Asylum Claims, September 2013, http://uklgig.org.uk/wp-content/ uploads/2014/02/Missing-the-Mark.pdf.

51 Millbank, "Gender, Sex and Visibility," 79.
52 Kimberlé Crenshaw, "Mapping the Margins: Intersectionality, Identity Politics, and Violence against Women of Color," Stanford Law Review 43 (1991): 1242.

53 Millbank, "Gender, Sex and Visibility," 83; Dauvergne and Millbank, "Burdened by Proof," 321.

54 Atrey, "Danger of a Single Story," 156.

55 Ibid., 158-9.

56 Ibid., 161.

57 Ibid., 156, 162.

58 Bhabha, "Internationalist Gatekeepers?", 162.

59 This principle has been recognized by appellate courts, as well as by the UNHCR: see, e.g., Appellant $S_{395 / 2002} v$ Minister for Immigration and Multicultural Affairs, (2003) 216 CLR 473; HJ (Iran) and HT (Cameroon), [2011] 1 AC 596; Un High Commissioner for Refugees, Guidelines on International Protection No. 9: Claims to Refugee Status Based on Sexual Orientation and/or Gender Identity within the Context of Article $1 A(2)$ of the 1951 Convention and/or its 1967 Protocol Relating to the Status of Refugees (2012), HCR/GIP/12/09. For a survey of jurisprudence on this question circa 2003, see Catherine Dauvergne and Jenni Millbank, "Before the High Court: Applicants S396/2002 and S395/2002, a Gay Refugee Couple from Bangladesh," Sydney Law Review 25 (2003): 115-17.

60 Berg and Millbank, "Constructing the Personal Narratives," 198.

61 Ibid., 199-200.

62 See, e.g., ibid., 206: "There are few even broadly common aspects in the experience of same-sex attraction."

63 On the potential inapplicability of the "stage model of sexual identity development" outside a Western cultural context, see Berg and Millbank, "Constructing the Personal Narratives," 206-8.

64 See, e.g., LaViolette, "Coming Out to Canada," 996; Berg and Millbank, "Constructing the Personal Narratives," 200: "The development of sexual identity is not universal or linear."

65 Millbank, "Imagining Otherness," 145.

66 Samani $v$ Canada (Minister of Citizenship and Immigration), 1998 CanLiI 8301 (FC) at para 4.

67 Jane Herlihy, Kate Gleeson, and Stuart Turner, "What Assumptions about Human Behaviour Underlie Asylum Judgments?", International Journal of Refugee Law 22 (2010): 358 .

68 An example of the use of country information in this manner is provided in ibid., 359.

69 Herlihy, Gleeso and Turner, "What Assumptions," 354; see also Pamela Heller, "Challenges Facing LGBT AsylumSeekers: The Role of Social Work in Correcting Oppressive Immigration Processes," Journal of Gay \& Lesbian Social Services 21 (2009): 295; Millbank, "Ring of Truth," 11, 15-16; Berg and Millbank, "Constructing the Personal Narratives," 197; Eddie Bruce-Jones, "Death Zones, Comfort Zones: Queering the Refugee Question," International Journal on Minority and Group Rights 22 (2015): 114. 
70 Rehaag, "Patrolling the Borders"; Sean Rehaag, "Bisexuals Need Not Apply: A Comparative Appraisal of Refugee Law and Policy in Canada, the United States, and Australia," International Journal of Human Rights 13 (2009): 415-36.

71 Bruce-Jones, "Death Zones," 114.

72 See, e.g., Rehaag, "Patrolling the Borders," 101.

73 Berg and Millbank, "Constructing the Personal Narratives," 213.

74 Rehaag, "Patrolling the Borders," 73-5, 83-6, 91-3; Rehaag, "Bisexuals Need Not Apply," 425.

75 Rehaag, "Patrolling the Borders," 86-7; Rehaag, "Bisexuals Need Not Apply," 424.

76 See, e.g., Fikri, "Asylum Seekers and 'Dishonest' Sexualities: Bisexuality at the Border," Autostraddle, 2 July 2014, https:// www.autostraddle.com/asylum-seekers-and-dishonestsexualities-bisexuality-at-the-border-243888.

77 Berg and Millbank, "Constructing the Personal Narratives," 211-13.

78 Bhabha, "Internationalist Gatekeepers?", 162.

79 Murray, Real Queer?, 67.

80 LaViolette, "Independent Human Rights Documentation," 455. On whether state protection ought to be presumed at all, see James C. Hathaway and Audrey Macklin, "Should We Presume State Protection," 32, no. 3 Refuge (2016): 49-53.

81 Bruce-Jones, “Death Zones," 116.

82 LaViolette, "Independent Human Rights Documentation," 453.

83 For a dissenting perspective, see Price, Rethinking Asylum.

84 Sharp, "Human Rights Fact-Finding," 75.

85 Bruce-Jones, "Death Zones," 109.

86 Gregor Noll, "Asylum Claims and the Translation of Culture into Politics," Texas International Law Journal 41 (2006): 492.

87 Bhabha, "Internationalist Gatekeepers?," 163-4. See also Murray, Real Queer?, 127.

88 See, e.g., Murray, Real Queer?, 126.

89 Millbank, "Imagining Otherness," 158.

90 Ibid., 160.

91 LaViolette, "Independent Human Rights Documentation," 450-4.

$92 M D$ at para 11.

93 Suresh Kumar Koushal and anor v NAZ Foundation and ors, Civil Appeal No 10972 of 2013.

94 For the history and operation of uk country guidance decisions, see, e.g., Robert Thomas, "Consistency in Asylum Adjudication: Country Guidance and the Asylum Process in the United Kingdom," International Journal of Refugee
Law (2008): 489-32. Calls for country guidance of this kind have a long history: Martin, "Reforming Asylum Adjudication," 1358.

95 United Kingdom Home Office, Country Information and Guidance-India: Sexual Orientation and Gender Identity, July 2014, http://www.refworld.org/docid/53ce6d614.html.

$96 M D$, paras $42-50$.

97 Ibid., para $18(\mathrm{~g})$.

98 Ibid., paras 22-3.

99 Ibid., para 137.

100 Ibid., para 111.

101 Ibid., para 18(b).

102 Ibid., para 131.

103 Ibid.

104 Ibid., para 141. Similar examples of inference from silence in Canadian RSD have been catalogued by LaViolette: "Independent Human Rights Documentation," 442-3, 44952. Findings of this kind were found to be particularly common in Australia by Dauvergne and Millbank: "Burdened by Proof," 310.

$105 M D$, para 144.

106 Ibid., para 145.

107 Ibid., para 151.

108 Ibid., para 148.

109 Ibid., para 174(e).

110 See Atrey on Chimamanda Ngozi Adichie's "concern with 'the danger of a single story"': Atrey, "Danger of a Single Story," 155, citing Chimamanda Ngozi Adichie, "The Danger of a Single Story," TED Talk, July 2009, http://www.ted.com/talks/ chimamanda_adichie_the_danger_of_a_single_story/ transcript?language $=$ en.

$111 M D$, para 180.

112 Ibid., para 177.

113 For criticism of this kind of assumption in RSD, see LaViolette, "Independent Human Rights Documentation," 451-2.

114 Alston and Knuckey, "Transformation of Human Rights Fact-Finding," 8.

115 Mégret, "Do Facts Exist," 38.

116 See also Kagan, "Is Truth," 376: "Refugee status determination is a human process; it is not an exact science."

Douglas McDonald-Norman is research assistant to the Hon. Dyson Heydon, QC (former justice of the High Court of Australia) and a former solicitor with Craddock Murray Neumann Lawyers. The author may be contacted at douglas. mcdonald719o@gmail.com. 